\title{
PENGARUH LOKASI TERHADAP KEPUTUSAN PEMBELIAN PENGUNJUNG DI MINIMARKET MENGGUNAKAN METODE REGRESI LINIER
}

\author{
Lia Nurlia $\left.{ }^{1}\right)$ \\ 1 ) Program Studi Manajemen, STIE Penguji Jl. KH. Ahmad Sanusi No.195, \\ Sukabumi, Jawa Barat 43135 (0266) 224675 \\ e-mail: Lia.nurlia@gmail.com ${ }^{1)}$ \\ * Korespondensi: e-mail:Lia.nurlia@gmail.com
}

\begin{abstract}
ABSTRAK
Dalam sistem swalayan, selain lokasi yang strategis, fasilitas pelayanan juga mempengaruhi jumlah pembeli. Fasilitas pelayanan adalah berbagai kemudahan yang diberikan oleh perusahaan terhadap konsumennya. Baik dalam bentuk fisik maupun non fisik. Berbagai pelayanan yang diberikan oleh swalayan tersebut diantaranya adalah jenisjenis barang yang disediakan sesuai dengan kebutuhan masyarakat, fasilitas penunjang pelayanan seperti ATM dan parkir yang dapat memberikan pelayanan dengan cepat kepada setiap pembeli ,Tanggapan pengunjung terhadap pengambilan keputusan dalam dalam berbelanja di Minimarket Sukabumi pada kondisi yang juga buruk, hal ini dapat dilihat dari nilai median empiric sebesar 37,5 yang juga lebih rendah dibanding median teoritik sebesar 42. Maka Berdasarkan perhitungan statistik, $\hat{Y}=-3,348+1,035 X$ variabel bebas memiliki hubungan searah (positif) dengan variabel terikatnya atau dengan kata lain terdapat hubungan searah antara lokasi minimarket dengan keputusan pembelian yang dibuat oleh pengunjung. Dan setelah dilakukan perhitungan korelasi linear sederhana, juga didapatkan variabel bebas memiliki hubungan searah (positif) dengan variabel terikatnya. Lokasi minimarket memiliki pengaruh terhadap proses keputusan pembelian yang dibuat oleh pengunjung, berdasarkan nilai $r^{2}$ 0,980 dapat dikatakan bahwa pengaruh yang diberikan antar variabel ini kuat dan signifikan.
\end{abstract}

Kata kunci :mini market, regresi, pengunjung

\begin{abstract}
In the self-service system, in addition to its strategic location, service facilities also affect the number of buyers. Service facilities are various facilities provided by the company to its customers. Both in physical and non-physical form. Various services provided by the supermarket include the types of goods provided in accordance with the needs of the community, supporting facilities such as ATMs and parking that can provide services quickly to every buyer, visitor response to decision making in shopping at the Minimarket Branch Sukabumi in a condition that is also bad, this can be seen from the median empiric value of 37.5 which is also lower than the theoretical median of 42. So based on statistical calculations, $=-3,348+1.035 X$ free variables have a direct relationship (positive) with the variable tied or in other words there is a direct relationship between the location Minimarket and the purchase decision made by the visitor. And after a simple linear correlation calculation, it is also obtained that free variables have a unidirectional (positive) relationship with the bound variables. The location of Indomaret has an influence on the purchasing decision process made by visitors, based on the value of $r^{2} 0.980$ it can be said that the influence exerted between these variables is strong and significant.
\end{abstract}

Keywords : Minimarket, Linear Regression, Visitors 


\section{Pendahuluan}

Dalam sistem swalayan, selain lokasi yang strategis, fasilitas pelayanan juga mempengaruhi jumlah pembeli.Fasilitas pelayanan adalah berbagai kemudahan yang diberikan oleh perusahaan terhadap konsumennya.Baik dalam bentuk fisik maupun non fisik.Berbagai pelayanan yang diberikan oleh swalayan tersebut diantaranya adalah jenis-jenis barang yang disediakan sesuai dengan kebutuhan masyarakat, fasilitas penunjang pelayanan seperti ATM dan parkir yang dapat memberikan pelayanan dengan cepat kepada setiap pembeli. [1]

Selain fasilitas pelayanan dalam bentuk fisik juga dibutuhkan pelayanan dalam bentuk non fisik, yaitu kemampuan berkomunikasi dari setiap penjaga atau karyawan yang bertugas di dalam swalayan itu sendiri. Kemampuan berkomunikasi yang dimaksudkan dalam hal ini adalah bagaimana karyawan tersebut membantu setiap pembeli yang berkunjung sehingga memudahkan pembeli untuk menemukan barang yang akan dibelinya serta sikap ramah dan sopan kepada pengunjung. [2]

Lokasi adalah letak usaha atau penjualan barang yang ditentukan perusahaan sehingga dapat dijangkau oleh konsumen. Lokasi yang strategis diartikan sebagai letak yang dapat dijangkau oleh konsumen dan memberikan berbagai kemudahan bagi konsumen dalam memenuhi kebutuhannya.[3]

Keputusan konsumen untuk membeli merupakan sikap konsumen yang memutuskan untuk membeli barang suatu barang atau jasa yang dibutuhkannya.Keputusan konsumen untuk membeli dipengaruhi oleh berbagai faktor. Sikap ramah dan sopan dari pramuniaga, serta adanya berbagai fasilitas-fasilitas layanan dan promosi yang baik akan menarik minat konsumen untuk melakukan pembelian.

Kenyamanan dan keamanan penggunaan fasilitas pelayanan tersebut akan menarik minat konsumen untuk melakukan pembelian produk di tempat tersebut. Selain fasilitas pelayanan dan lokasi yang mudah dijangkau oleh konsumen akan menjadi pilihan utama dalam melakukan pembelian. [4]

\section{Penelitian Terkait}

\subsection{Teori Pemasaran}

Pemasaran adalah sistem keseluruhan dari kegiatan-kegiatan bisnis yang ditujukan untuk merencanakan, menentukan harga, mempromosikan, dan mendistribusikan barang dan jasa untuk memuaskan kebutuhan, baik kepada pembeli yang ada maupun pembeli potensial (Stanton, 2007:47).

Menurut Kotler (2000 : 221), pemasaran adalah proses sosial dan manajerial di mana individu dan kelompok mendapatkan apa yang mereka butuhkan dan inginkan dengan menciptakan, menawarkan, dan mempertukarkan produk dengan pihak lain. 


\subsection{Teori tentang Perilaku Konsumen}

Perilaku konsumen adalah kegiatan-kegiatan individu yang secara langsung terlibat dalam mendapatkan dan menggunakan barang dan jasa termasuk di dalamnya proses pengambilan keputusan pada persiapan dan penentuan kegiatan-kegiatan tersebut (Swastha, 2004 : 97).

\section{a. Kerangka berpikir}

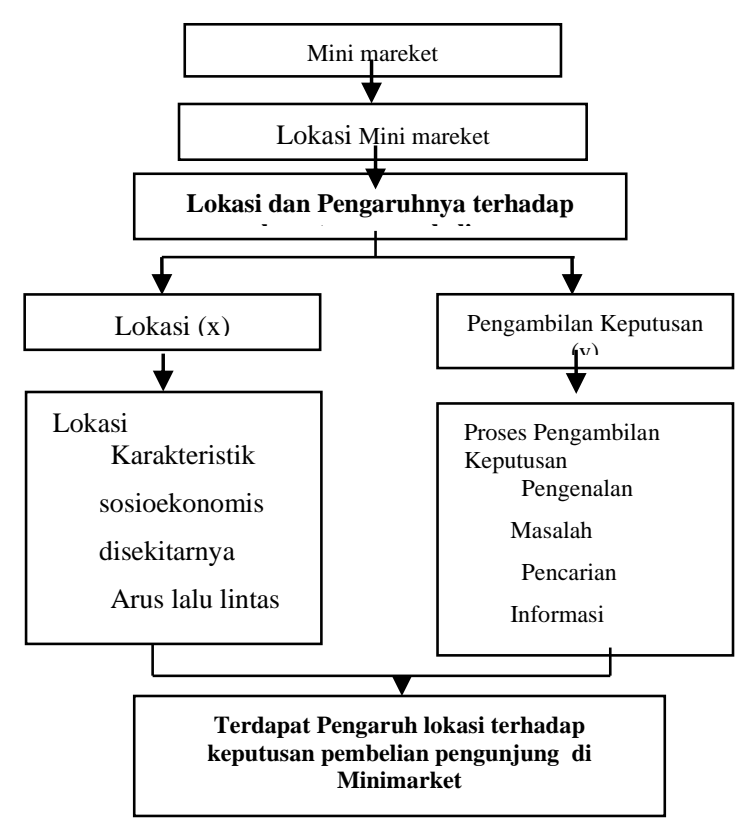

Gambar 2.1 kerangka berpikir

\section{Metodologi}

\subsection{Metode Pengumpulan Data}

Untuk mengumpulkan data mengenai objek penelitian, maka digunakan metode pengumpulan data sebagai berikut:

1. Penelitian lapangan (Field Research) yang terdiri dari:

a. Teknik wawancara (interview), yaitu dengan melakukan tanya jawab atau wawancara langsung kepada pengunjung Minimarket di Kabupaten Sukabumi yang menjadi objek penelitian. Teknik ini dilaksanakan dalam jumlah sampel terbatas dan akan dijadikan salah satu rujukan dalam penyusunan kuesioner ataupun hasil akhir 
b. Kuesioner, yaitu teknik pengumpulan data primer yang dilakukan melalui penyebaran kuesioner kepada sejumlah sampel responden yang dianggap dapat mewakili seluruh populasi yang akan diteliti berdasarkan metode statistik tertentu yang akan dilaksanakan pada pengunjung Minimarket di Kabupaten Sukabumi di tempat tersebut dan pada setiap hari dari Jam 13.00 s.d Jam 15.00 selama bulan September.

c. Teknik Observasi, yaitu dengan melakukan pengamatan langsung terhadap kegiatan pembelian di Minimarket Sukabumi yang juga akan digunakan sebagai sumber penyusunan kuesioner.

\subsection{Operasional Variabel}

Yang akan diteliti adalah Minimarket di Kabupaten Sukabumi pada pengunjung sebagai variabel bebas atau independen (Variabel X) dan keputusan pembelian sebagai variabel tidak bebas atau dependen (Variabel Y).

Variabel lokasi indomaret adalah skor total yang diperoleh variabel ini dari hasil angket yang disebarkan pada pengunjung.

\subsection{Metode Analisis Data}

\subsubsection{Uji Validitas}

Uji Validitas digunakan untuk menguji ketetapan setiap item dalam mengukur instrumennya, teknik uji yang digunakan adalah teknik korelasi item total melalui Koefisien Korelasi Pearson. Skor setiap item pertanyaan yang diuji kevalidannya dikorelasikan dengan skor total seluruh item (Sugiyono, 2000:106). Jika koefisien korelasi Pearson positif dan signifikan maka item valid, jika non signifikan, nol, atau negatif maka item tidak valid (Singarimbun, 1995:139). Item yang tidak valid disisihkan dari kuesioner dan digantikan dengan item perbaikan.

Rumus Koefisien Korelasi Product Moment Pearson:

$\mathrm{r}_{\mathrm{s}}=$ Koefisien Korelasi

$\mathrm{n}=$ Jumlah responden

$\mathrm{Y}=$ Jumlah skor total seluruh item

$\mathrm{X}=$ Jumlah skor tiap item

\subsubsection{Uji Reliabilitas}

Uji Reliabilitas dilakukan untuk menguji kehandalan atau konsistensi instrumen. Item-item yang dilibatkan dalam uji reliabilitas ini adalah seluruh item yang valid atau setelah setelah item yang tidak valid disisihkan. Teknik uji yang digunakan adalah metode alpha cronbach. Nilai Koefisien Korelasi yang diperoleh kemudian digunakan untuk mengukur reliabilitas instrumen dengan mentransformasikan ke dalam rumus Koefisien Reliabilitas Spearman-Brown sebagai berikut: 
$\mathrm{r}_{\mathrm{b}}=$ Koefisien Korelasi Pearson antara skor total belahan ganjil dengan genap

Jika Koefisien Reliabilitas Spearman-Brown positif dan signifikan maka instrumen reliabel, jika non signifikan, nol, atau negatif maka instrumen tidak reliabel (Singarimbun, 1995:139).Item yang tidak valid disisihkan dari kuesioner atau digantikan dengan item perbaikan.

\subsubsection{Analisis Statistik}

Untuk menjawab masalah dan mengungkaptujuan penelitian, pertama digunakan metode analisis deskriptif berdasarkan kuesioner dan wawancara.Pelaksanaan meliputi pengumpulan data, penyusunan data, dan interpretasi tentang arti data tersebut.

Metode analisis yang digunakan untuk menjawab masalah dan mengungkaptujuan penelitian kedua yaitu pengaruh Lokasi Indomaret terhadap keputusan pembelian pengunjung adalah metode kualitatif dan kuantitatif dimana:

$>$ Metode kualitatif, mengemukakan data-data yang didapat dengan mengelompokkan, mentabulasi, dan memberikan penjelasan.

$>$ Metode kuantitatif, dilakukan dengan menggunakan alat bantu statistik. Metode statistik yang digunakan untuk menganalisis hubungan variabel yang diteliti.

\section{Analisis Korelasi Linier Sederhana}

Digunakan untuk mengetahui derajat korelasi antara variabel bebas dengan variabel terikat yang akan diuji dengan menggunakan Ms Excel for Windows dan Spss versi 20.

Koefisien Korelasi terletak antara -1 dan 1, dimana:

$\mathrm{r}_{\mathrm{xy}}=1$, artinya hubungan Linier Positif Sempurna antara X dan Y. Jika Nilai X bertambah besar, maka nilai Y juga bertambah besar dan demikian pula sebaliknya.

$\mathrm{r}_{\mathrm{xy}}=-1$, artinya hubungan Linier Negatif Sempurna antara $\mathrm{X}$ dan Y. Jika Nilai X bertambah besar, maka nilai $\mathrm{Y}$ bertambah kecil dan demikian pula sebaliknya.

$\mathrm{r}_{\mathrm{xy}}=0$, artinya tidak ada hubungan Linier antara $\mathrm{X}$ dan $\mathrm{Y}$.

Untuk mencari Koefisien Korelasi yang mengukur besarnya kontribusi X terhadap Y adalah menggunakan Product Moment Method Correlation Analysis:

Data yang digunakan untuk menguji konseptual yang dikemukakan dalam suatu penelitian merupakan data yang berasal dari suatu sampel yang berukuran n, maka harus diuji keberartian koefisien korelasi dengan menggunakan uji statistik t sebagai berikut:

Pada akhirnya, nilai $t$ hitung yang didapat dibandingkan dengan $t_{\text {tabel }}$ dengan $d_{\mathrm{f}}=n-2$, pada taraf kesalahan $\alpha=$ 0,05 dua sisi dan kriteria penolakannya adalah:

Tolak Ho dan Hi diterima apabila $\mathrm{t}_{\text {hitung }}>\mathrm{t}_{\text {tabel }}$ atau $\mathrm{t}_{\text {hitung }}<\mathrm{t}_{\text {tabel }}$ maka Ho diterima dan Hi ditolak. Ho : Lokasi berpengaruh terhadap keputusan pembelian pengunjung di Mini market Sukabumi. 
Hi : Lokasi tidak berpengaruh terhadap proses keputusan pembelian pengunjung di Mini market Sukabumi.

Data yang digunakan untuk mengetahui berapa persen pengaruh yang diberikan variabel $\mathrm{X}$ secara stimulant terhadap variabel $\mathrm{Y}$ adalah $\mathrm{r}^{2}$ yang disebut dengan (Koefisien determinasi).

Metode regresi linear bertujuan untuk mengetahui ada tidaknya pengaruh variabel besar X terhadap variabel terikat $\mathrm{Y}$, dimana persamaannya sebagai berikut :

$\mathrm{Y}=\mathrm{a}+\mathrm{bX}$

Keterangan :

$\mathrm{a}=$ konstanta

$\mathrm{b}=$ koefisien regresi

$$
t=r
$$

$$
b=\frac{n\left(\sum X Y\right)-\left(\sum X\right)\left(\sum y\right)}{n\left(\sum X^{2}\right)-\left(\sum X\right)^{2}}
$$

\section{Hasil Penelitian}

\subsection{Data Tanggapan Responden mengenai Lokasi Minimarket}

Hasil penelitian terhadap variabel lokasi Minimarket dapat dilihat pada tabel berikut:

Tabel 4.1 Distribusi

\begin{tabular}{|c|c|c|}
\hline No & $\begin{array}{l}\text { Kelas } \\
\text { interval }\end{array}$ & Frekuensi \\
\hline 1 & $21-26$ & 6 \\
\hline 2 & $27-32$ & 6 \\
\hline 3 & $33-38$ & 17 \\
\hline 4 & $39-44$ & 10 \\
\hline 5 & $45-50$ & 12 \\
\hline 6 & $51-56$ & 6 \\
\hline 7 & $57-61$ & 1 \\
\hline Jumlah & & 58 \\
\hline
\end{tabular}

Frekuensi Variabel Lokasi minimarket

\begin{tabular}{|l|l|}
\hline Mean & 40.26 \\
\hline Median & 40.5 \\
\hline Mode & 43 \\
\hline Range & 40 \\
\hline Minimum & 21 \\
\hline Maximum & 61 \\
\hline Sum & 2335 \\
\hline Count & 58 \\
\hline
\end{tabular}


Dari distribusi frekuensi tersebut dapat diketahui perhitungan statistika dasar

Berdasarkan data penelitian, skor variabel bebas yaitu Lokasi Indomaret yang dikumpulkan melalui angket mempunyai rentang skor teoritik 21-61. rentang skor tersebut diperoleh berdasarkan jumlah item pada angket, yaitu sebanyak 14 item yang disusun berdasarkan skala likert dengan 5 pilihan jawaban. Dengan demikian diperoleh rentang skor teoritik minimum adalah 14 dan skor teoritik maksimum adalah 70, kemudian median teoritik adalah $(14+70): 2$ $=42$. Adapun data empirik merupakan data yang diperoleh berdasarkan hasil survei melalui penyebaran angket. Skor median empiric didapat 40.5 lebih kecil dari skor median teoritik. Ini berarti tanggapan masyarakat terhadap lokasi Indomaret tidak terlalu baik.

\subsection{Data Tanggapan Responden mengenai Proses Keputusan Pembelian}

Hasil penelitian terhadap variabel keputusan pembelian dapat dilihat pada tabel berikut:

Tabel 4.2 Distribusi Frekuensi Variabel keputusan pembelian

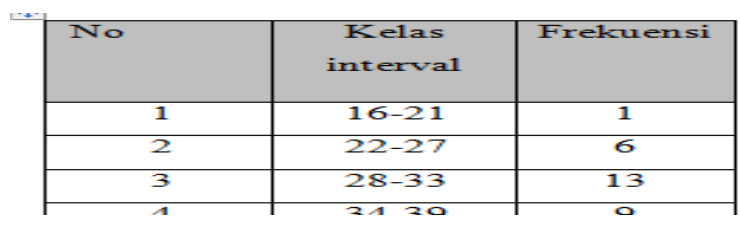

\begin{tabular}{|l|l|}
\hline Mean & 38.31 \\
\hline Median & 37.5 \\
\hline Mode & 35 \\
\hline Range & 42 \\
\hline Minimum & 16 \\
\hline Maximum & 58 \\
\hline Sum & 2222 \\
\hline Count & 58 \\
\hline
\end{tabular}

Berdasarkan data penelitian, skor variabel bebas yaitu proses keputusan pembelian yang dikumpulkan melalui angket mempunyai rentang skor teoritik 16-58. Rentang skor tersebut diperoleh berdasarkan jumlah item pada angket, yaitu sebanyak 14 item yang disusun berdasarkan skala likert dengan 5 pilihan jawaban. Dengan demikian diperoleh rentang skor teoritik minimum adalah 14 dan skor teoritik maksimum adalah 70, kemudian median teoritik adalah $(14+70): 2$ $=42$. Adapun data empirik merupakan data yang diperoleh berdasarkan hasil survei melalui penyebaran angket. Skor median empiric didapat 37.5 lebih kecil dari skor median teoritik. Ini berarti tanggapan masyarakat terhadap proses keputusan pembelian tidak terlalu baik. 


\subsection{Analisis Pengaruh Lokasi terhadap Keputusan Pembelian pengunjung Mini market}

Hasil uji Validitas dan reliabilitas menunjukkan bahwa instrumen lokasi Indomaret dan keputusan pembelian pengunjung adalah valid dan reliabel.Semakin tinggi nilai koefisien validitas dan reliabilitas suatu instrumen menunjukkan semakin tingginya keandalan instrumen tersebut.

Tabel hasil uji reliabilitas tersebut menunjukkan bahwa untuk setiap variabel penelitian yang dipergunakan telah memenuhi kriteria valid dan reliabel.Hal ini memberikan informasi bahwa jawaban responden terhadap kuesioner yang dipergunakan memperlihatkan kekonsistenan, sehingga hasil perolehan skor jawaban kuesioner dapat dipergunakan dan dianalisis lebih lanjut.

Dari kedua tabel validitas dan reliabilitas di bawah (Variabel X dan Y) dapat dilihat bahwa koefisien korelasi product moment pearson dan reliabilitas Alpha cronbach positif dan signifikan, maka instrumen dapat dinyatakan valid dan reliabel sehingga tidak diperlukan adanya penyisihan item dari kuesioner atau tidak perlu ada pergantian dengan item perbaikan.

Tabel 4.3 tabel rangkuman uji validitas

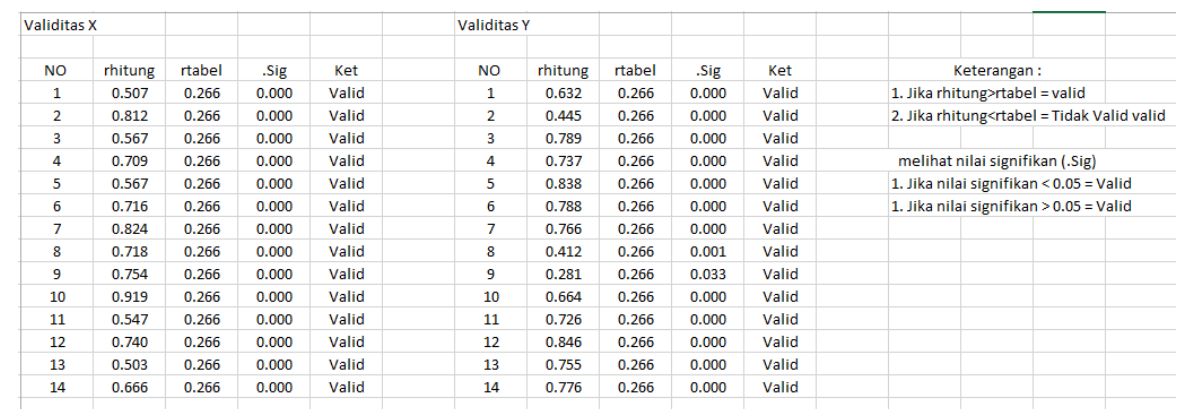

Tabel 4.4 tabel uji reliabilitas

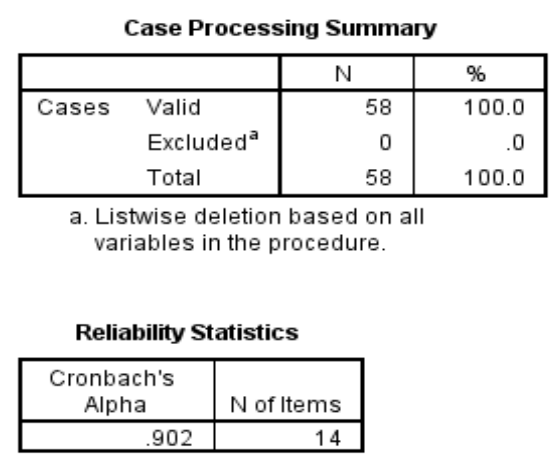

\begin{tabular}{|c|c|c|c|}
\hline \multicolumn{4}{|c|}{ Case Processing Summary } \\
\hline & & $\mathrm{N}$ & $\%$ \\
\hline \multirow{3}{*}{ Cases } & Valid & 58 & 100.0 \\
\hline & Excluded $^{a}$ & 0 & .0 \\
\hline & Total & 58 & 100.0 \\
\hline
\end{tabular}

Reliability Statistics

\begin{tabular}{|r|r|}
\hline $\begin{array}{c}\text { Cronbach's } \\
\text { Alpha }\end{array}$ & N of Items \\
\hline .910 & 14 \\
\hline
\end{tabular}




\subsubsection{Uji Normalitas Data}

Pengujian normalitas data dalam penelitian ini dilakukan melalui uji one sample kolmogorov smirnov.Kriteria pengujian adalah jika (Asymp.Sig. (2-tailed) lebih besar dari signifikansi 0,05, artinya nilai residual tersebut adalah normal, sebaliknya jika (Asymp.Sig. (2-tailed) lebih kecil dari signifikansi 0,05, artinya nilai residual tersebut adalah tidak normal,

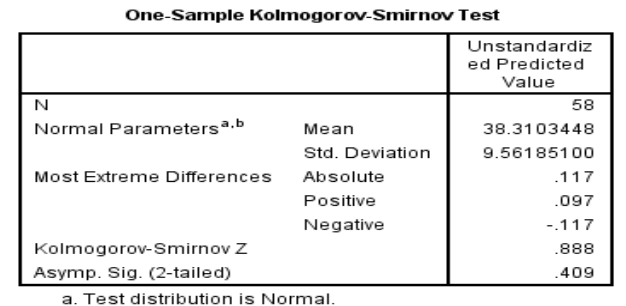

Dari tabel diatas dapat disimpulkan bahwa residual bersifat normal. Hal ini karena (Asymp.Sig. (2-tailed) lebih besar dari signifikansi 0,05 .

\subsubsection{Uji Kebermaknaan Arah Regresi}

Uji kebermaknaan arah regresi dalam penelitian ini dimaksudkan untuk melihat kebermaknaan arah hubungan antara variabel Lokasi (X) dan variabel keputusan pembelian pengujung (Y).

Pengujian kebermaknaan arah regresi menggunakan uji $\mathrm{F}$, yang didasarkan atas pendekatan analisis varian (ANOVA) pada taraf signifikansi 0,05. Kebermaknaan hubungan antara Y dengan X yang menunjukkan arah regresi yang signifikan atau tidak.

Pengujian kebermaknaan arah regresi juga menggunakan uji $\mathrm{F}$, yang didasarkan atas pendekatan analisis varians (ANOVA) pada taraf signifikansi 0,05. Ketentuan yang dipakai untuk uji kebermaknaan arah regresi adalah jika perhitungan menentukan $F$ Hitung lebih besar dari $F_{\text {tabel }}$ pada taraf nyata 0,05 atau 5\% disimpulkan koefisien arah regresi bermakna signifikan, sebaliknya jika ternyata Thitung lebih besar dari $F_{\text {tabel }}$ pada taraf nyata 0,05 atau $5 \%$ disimpulkan koefisien arah regresi tidak signifikan atau tidak bermakna. Hasil perhitungan uji kebermaknaan arah regresi itu dapat dirangkum dalam tabel berikut.

Tabel 4.5 Rangkuman Hasil UjiKebermaknaan Arah Regresi

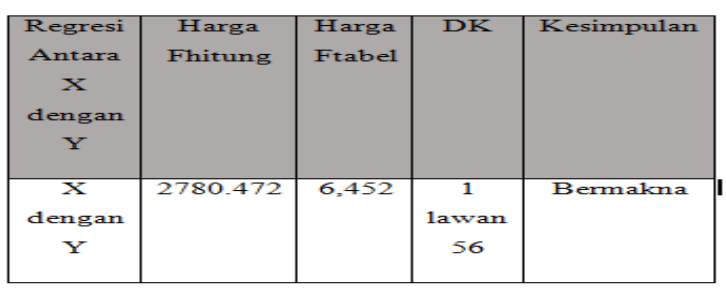


Keterangan : $\quad$ Y : keputusan pembelian pengunjung

$$
\mathrm{X} \text { : Lokasi Indomaret }
$$

Berdasarkan table di atas ternyata uji kebermaknaan arah regresi menunjukkan hubungan $\mathrm{X}$ dengan $\mathrm{Y}$ bermakna pada derajat kebebasan pembilang satu dan derajat kebebasan menyebut 1 dan hubungan $\mathrm{X}$ dengan $\mathrm{Y}$ bermakna pada derajat kebebasan pembilang 1 dan derajat kebebasan menyebut 58.

Setelah dilakukan uji persyaratan uji normalitas, dan kebermaknaan ternyata data yang berhasil penulis kelompokkan tergolong normal, dan bermakna.Dengan demikian memenuhi syarat untuk dilanjutkan ke uji statistik parametrik.

\subsection{Pengujian Hipotesis}

Pengujian hipotesis merupakan langkah penulis dalam membuktikan apakah hipotesis nol $\left(\mathrm{H}_{\mathrm{o}}\right)$ dan hipotesis kerja $\left(\mathrm{H}_{1}\right)$ dalam penelitian ini dapat diterima atau ditolak.Penghitungan yang harus dilakukan pada uji hipotesis ini meliputi penghitungan korelasi, regresi serta determinasi.

Hipotesis penelitian adalah terdapat pengaruh Lokasi (X) terhadap keputusan pembelian (Y), secara statistik diperoleh $r_{y}=0.980$, yang berarti terdapat pengaruh positif antara variabel Lokasi Indomaret $(\mathrm{X})$ terhadap variabel keputusan pembelian (Y). Lokasi Indomaret (X) terhadap variabel keputusan pembelian pengunjung (Y) secara linear ditunjukkan oleh persamaan regres $\hat{Y}=-3,348+1,035 X$.

Kekuatan pengaruh variabel $\mathrm{X}$ terhadap variabel $\mathrm{Y}$ ditunjukkan oleh nilai signifikansi koefisien korelasi $_{\mathrm{y} 1}=$ 0,980 Hasil uji signifikansi tersebut penulis tabelkan sebagai berikut.

Tabel 4.6. Uji Signifikansi Koefisien Korelasi X dengan Y

\begin{tabular}{|c|c|c|c|c|}
\hline $\begin{array}{c}\text { Korelasi } \\
\text { antara }\end{array}$ & $\begin{array}{c}\text { Koefisien } \\
\text { kolerasi }\end{array}$ & $\begin{array}{c}\text { Koefisien } \\
\text { determinan }\end{array}$ & $\mathbf{t}_{\text {hitung }}$ & $\boldsymbol{t}_{\text {tabel }}$ \\
\hline $\begin{array}{c}\text { X } \\
\text { terhadap } \\
Y\end{array}$ & 0,990 & 0,980 & 52,730 & 2,447 \\
\hline
\end{tabular}

Keterangan : $\quad$ Y : keputusan pembelian pengunjung

$$
\text { X : lokasi indomaret }
$$

Pada perhitungan tabel di atas tampak t hitung sebesar 52,730 sedangkan dari tabel distribusi student " $\mathrm{t}$ " dengan dk 58 pada taraf signifikansi 0,05 diperoleh harga $t_{\text {tabel }}$ 2,447 terbukti, $t$ hitung lebih besar dari t tabel maka dapat disimpulkan bahwa variansi variabel Y dapat dijelaskan oleh X. Terbukti, koefisien korelasi antara X dengan Y sebesar 0,990 tergolong signifikan. 
Selanjutnya diperoleh koefisien determinasi $\left(\mathrm{r}_{\mathrm{y}}{ }^{2}\right)$ sebesar 0,980 berarti variansi variabel $\mathrm{Y}$ dapat dijelaskan oleh X sebesar 98,00\% melalui persamaan regresi $\hat{Y}=-3,348+1,035 X$. Sedangkan sisanya sebesar 2,00 \% dijelaskan oleh variabel lain yang tidak diungkap.

\section{BAB V KESIMPULAN}

\subsection{Kesimpulan}

Berdasarkan hasil penelitian dan pembahasan pada bab sebelumnya, maka dapat disimpulkan sebagai berikut:

1. Tanggapan pengunjung terhadap lokasi Minimarket Sukabumi pada kondisi yang buruk, hal ini dapat dilihat dari nilai median empiric sebesar 40,5 lebih rendah dibanding median teoritik sebesar 42.

2. Tanggapan pengunjung terhadap pengambilan keputusan dalam dalam berbelanja di Minimarket Sukabumi pada kondisi yang juga buruk, hal ini dapat dilihat dari nilai median empiric sebesar 37,5 yang juga lebih rendah dibanding median teoritik sebesar 42 .

3. Berdasarkan perhitungan statistik, $\hat{Y}=-3,348+1,035 \mathrm{X}$ variabel bebas memiliki hubungan searah (positif) dengan variabel terikatnya atau dengan kata lain terdapat hubungan searah antara lokasi minimarket dengan keputusan pembelian yang dibuat oleh pengunjung. Dan setelah dilakukan perhitungan korelasi linear sederhana, juga didapatkan variabel bebas memiliki hubungan searah (positif) dengan variabel terikatnya. Lokasi Indomaret memiliki pengaruh terhadap proses keputusan pembelian yang dibuat oleh pengunjung, berdasarkan nilai $r^{2}$ 0,980 dapat dikatakan bahwa pengaruh yang diberikan antar variabel ini kuat dan signifikan. 


\section{DAFTAR PUSTAKA}

[1] K. Ria, M. Antari, K. Dunia, and L. Indrayani, "Pengaruh Lokasi Dan Harga Terhadap Keputusan Berbelanja Pada Mini Market Sastra Mas Tabanan,” vol. 4, 2014.

[2] A. D. Lutfianto, "Pengaruh Harga Dan Kualitas Layanan Terhadap Kepuasan Pelanggan,” J. Ilmu dan Ris. Manaj., vol. 4(8), pp. 1-9, 2015.

[3] A. W. S. Gama, N. W. Rustiarini, and N. P. N. Anggraini, "PENGARUH LOKASI, FASILITAS, DAN PELAYANAN TERHADAP KEPUTUSAN PEMBELIAN (Studi Pada Pasar Seni Guwang Sukawati) Agus,” vol. 11, no. 1, pp. 22-30, 2016.

[4] C. Safitasri and I. Maftukhah, "Pengaruh Kualitas Pelayanan, Promosi Dan Citra Destinasi Terhadap Kepuasan Melalui Keputusan Berkunjung," Unkn. Values Stakeholders, vol. 6, no. 3, pp. 221-241, 2017.

[5] Assauri, S.1997. Manajemen Pemasaran: Dasar, konsep dan strategi. Rajawali Press. Jakarta

[6] Azwar, Saifudin.2003. Reliabilitas dan Validitas. Pustaka Pelajar. Yogyakarta.

[7] Engel, James F, Black Well, Roger D, dan Miniard, Paul W. 1994. Perilaku Konsumen.Terjemahan Budiyanto. Binarupa Aksara. Jakarta.

[8] Ghozali, Imam. 2005. Aplikasi Analisis Multivariate dengan Program SPSS. Edisi

[9] Ketiga. Badan Penerbit Universitas Diponegoro. Semarang.

[10] Guiltinan, P.Y. dan Paul W. Gordon . 2002. Strategi dan Program Manajemen

[11] Pemasaran. Alih Bahasa : Agus Maulana. Gelora Aksara Pratama. Jakarta.

[12] Harmaizar dan Risidayati Rozalina 2003. Pedoman Lengkap Pendirian dan

Pengembangan Usaha. Edisi Pertama.CV Dian Anugerah Prakarsa.Bekasi.

[13] Kotler, Philip. 1993. Manajemen Pemasaran. Terjemahan Drs. Jaka Wasana, Institut Pendidikan dan Pembinaan Manajemen. Edisi Keenam. Erlangga.Jakarta.

[13] Kotler, Philip dan AB Susanto. 2001. Manajemen Pemasaran. Terjemahan

[14] Hendra Teguh, Ronny A. Rusli dan Benjamin Molan. Edisi Milenium. Prenhallindo. Jakarta.

[15] Kuncoro, Mudrajad. 2004. Metode Kuantitatif :Teori dan Aplikasi untuk Bisnis dan Ekonomi. Unit Penerbit dan Percetakan YKPN.Yogyakarta.

[16] Lamb, Chales W, Hair, Joseph F., dan McDaniel , Carl. 2001. Pemasaran

Penerjemah David Octarevia. Salemba Empat Jakarta.

[17] Rahadja, Prathama dan Mandala Manurung. 2000. Teori Ekonomi Mikro. Fakultas Ekonomi. Universitas Indonesia. Jakarta.

[18] Santoso, Singgih.2005. SPSS Mengolah Data Statistik Secara Profesional.PT. Elexmedia Komputindo. Jakarta.

[19] Stanton, William J. 1993. Prinsip Pemasaran. Edisi Ketujuh, Alih Bahasa Y. Lamarto. Erlangga. Jakarta.

[20] Sutojo, Siswanto.1998. Azas-azas Pemasaran.Erlangga. Jakarta. 